\title{
IL-10 Controls Aspergillus fumigatus- and Pseudomonas aeruginosa-Specific T-Cell Response in Cystic Fibrosis
}

\author{
CARMEN CASAULTA, MARTIN H. SCHÖNI, MICHAEL WEICHEL, RETO CRAMERI, \\ MAREK JUTEL, ISABELLE DAIGLE, MÜBECCEL AKDIS, KURT BLASER, AND \\ CEZMI A. AKDIS \\ Department of Pediatrics [C.C., M.H.S.], University Children's Hospital, Inselspital, Bern, Switzerland; \\ Swiss Institute of Allergy and Asthma Research [M.W., R.C., I.D., M.A., K.B., C.A.A.], Davos, \\ Switzerland; and Medical University of Wroclaw [M.J.], Wroclaw, Poland.
}

\begin{abstract}
Up to $90 \%$ of patients with cystic fibrosis (CF) are chronically colonized with Pseudomonas aeruginosa, and $10 \%$ to $50 \%$ of CF patients are colonized with Aspergillus fumigatus. Despite an extensive inflammatory reaction, patients cannot eliminate the microorganisms. The present study demonstrates that an IL-10 mediated T-cell tolerance to major infectious agents $A$. fumigatus and $P$. aeruginosa plays an important role in the control of T-cell-mediated inflammatory responses in CF. Peripheral blood mononuclear cells of CF patients secreted significantly higher amounts of IL-10. T-cell response against recombinant $A$. fumigatus antigens rAsp f 3 , rAsp f 4 , rAsp $\mathrm{f} 6$, and heatinactivated $P$. aeruginosa was controlled by IL-10. Proliferation and interferon- $\gamma$ production was significantly increased when endogenous IL-10 was blocked in aspergillus and pseudomonas antigen-stimulated cells of CF patients. The role of IL-10 was further documented by increased spontaneous proliferation of peripheral blood mononuclear cells of CF patients after preincu-
\end{abstract}

\section{ABSTRACT}

bation with antisense oligonucleotides blocking the synthesis of IL-10 receptor-associated kinases janus tyrosine kinase 1 and tyrosine kinase 2 . Together, these data demonstrate an important role of IL-10-mediated peripheral T-cell tolerance to $P$. aeruginosa and $A$. fumigatus in the control of the intensity of the inflammatory T-cell response in CF. (Pediatr Res 53: 313-319, 2003)

CF, cystic fibrosis

\section{Abbreviations}

ABPA, allergic bronchopulmonary aspergillosis

IFN- $\boldsymbol{\gamma}$, interferon- $\boldsymbol{\gamma}$

PBMC, peripheral blood mononuclear cells

rAsp, f 3/4/6 recombinant Aspergillus fumigatus antigen 3/4/6

BAL, bronchoalveolar lavage

Jak 1, Janus tyrosine kinase 1

Tyk 2, tyrosine kinase 2
The chronic pulmonary infection and the ensuing destructive inflammatory process is still the major cause of morbidity and mortality in cystic fibrosis (CF) patients despite great progresses in antimicrobial therapy (1). Efforts are made to understand the inflammatory mechanisms in the CF lung and to find out why microorganisms such as Pseudomonas aeruginosa can escape the definitive elimination by the immune system and therefore cause an endless inflammation. Aspergillus fumigatus is a ubiquitous mold found in up to $50 \%$ of $\mathrm{CF}$ respiratory secretions (2). The interaction between $A$. fumigatus and the host organism ranges from simple colonization to allergic bronchopulmonary aspergillosis (ABPA), which may

Received January 25, 2002; July 12, 2002.

Correspondence: Carmen Casaulta, M.D., University Children's Hospital, Inselspital, CH-3010 Bern, Switzerland; e-mail: carmen.casaulta@insel.ch

This study was supported by Swiss National Foundation grants 32.65661.01, and 31.65433.01. C.C. was supported by the Silva Casa Foundation.

DOI: 10.1203/01.PDR.0000047528.79014.CF rarely lead to invasive aspergillosis in immune-compromised individuals (3). Characterization, cloning, and production of some recombinant allergens from $A$. fumigatus improved the diagnostic possibilities (4-7). At present, several recombinant antigens are available for determination of specific $\operatorname{IgE}$ against A. fumigatus (7-9). Distinct patterns of specific antibodies were found in patients with and without ABPA. Whereas patients sensitized to $A$. fumigatus show specific IgE antibodies to rAsp $\mathrm{f} 1$ and rAsp $\mathrm{f} 3$, patients with ABPA also show specific antibodies to two intracellular antigens of $\mathrm{A}$. fumigatus, rAsp f 4 and/or rAsp f 6 (10). In patients who develop ABPA, A. fumigatus contributes undoubtedly to the severe course of disease, and like $P$. aeruginosa, A. fumigatus cannot be eliminated effectively from the lung in most patients. Elevated levels of proinflammatory cytokines such as IL-1 $\beta$, IL-6, IL-8, and tumor necrosis factor- $\alpha$ were found in serum $(11,12)$ and in bronchoalveolar lavage fluid (BAL) of CF patients (13). Alveolar macrophages are the predominant phagocytes recov- 
ered by BAL in healthy individuals. In stable CF patients or in very young children and infants with little clinical evidence of lung problems and mild illness, mostly neutrophils are recovered from BAL $(14,15)$. Besides perpetuating the inflammatory response, neutrophils themselves may directly injure the lung by releasing oxygen metabolites as well as lysosomal enzymes and proteases (16).

IL-10, a major regulatory cytokine of inflammatory responses, was identified originally as an inhibitor of IFN- $\gamma$ and IL-2 synthesis in T-cells. Evidence demonstrates that IL-10 is a general inhibitor of activation and cytokine production in T-cells, neutrophils, and macrophages. IL-10 is produced by macrophages $(17,18)$, natural killer cells $(19)$, and both Th1and Th2-type lymphocytes (20). IL-10 plays an important role in T-cell behavior as demonstrated in different mouse models (21), in natural antigen exposure, and in increased allergen administration during allergen-specific immunotherapy (22, 23). The suppressor effect of IL-10 on T-cells has recently been demonstrated to be primarily directed to block the costimulatory signal for activation in T-cells. IL-10 inhibits CD28 signaling cascade and subsequent phosphatidylinositol 3-kinase activation in T-cells (23). IL-10 receptor contains $\alpha$ and $\beta$ chains, and triggering of the IL-10 receptor (R) results in phosphorylation of the receptor-associated protein tyrosine kinases Jak 1 and Tyk $2(24,25)$ and the following activation of signal transduction and activation of transcription $1 \alpha$ and 3 (24). Because IL-10 has been shown to inhibit T-cell activation and proinflammatory cytokine production, changes in IL-10 secretion may efficiently contribute to the inflammatory response in CF. In addition, IFN- $\gamma$ was studied as a Th1 type and IL-13 as a Th2 type cytokine to give a better insight into the immunologic mechanisms in CF. Thus, the present study demonstrates that IL-10 is essential in regulation of the lung inflammatory response. In CF patients, A. fumigatus - and $P$. aeruginosa-induced increased amounts of IL-10 controls the aspergillus- and pseudomonas-specific T-cell responses.

\section{METHODS}

Subjects. Seventeen patients with CF (mean age: $20.0 \pm$ $10.2 \mathrm{y}$; range: $8-44.5 \mathrm{y}$; median: $17.5 \mathrm{y}$ ) were recruited from the CF outpatient clinics of the University Children's Hospital in Berne, Switzerland. Their mean forced expiratory volume in $1 \mathrm{~s}$ was $60.1 \pm 24.3 \%$ of the value predicted for sex and height (range: 30-100\%; median: 55\%; lung function of patients older than 18 y were based on adult predicted values), and the mean forced vital capacity was $74.1 \pm 22.0 \%$ of predicted values (range: $36-105 \%$; median: $74 \%$ ). Seven patients (mean age: $17.9 \pm 10.9$ y; range: $8-39.8 \mathrm{y}$; median: $17.5 \mathrm{y}$ ) received a diagnosis of ABPA in the last 12 mo according to Nelson's criteria (2). Their immunologic values in serum were as follows (mean $\pm \mathrm{SD}$ ): total $\mathrm{IgE} 2150.7 \pm 1758.8 \mathrm{kU} / \mathrm{L}$ (range: 500-5662 kU/L; median: $1912.0 \mathrm{kU} / \mathrm{L}$ ), A. fumigatus RAST class $4.3 \pm 0.8$ (range: $3-5$; median: 4.0 ). Specific IgE against recombinant $A$. fumigatus antigens was measured as $\mathrm{rAsp} \mathrm{f} 1$ : $128 \pm 94 \mathrm{EU} / \mathrm{L}$ (range: 46-278 EU/L; median: $80.0 \mathrm{EU} / \mathrm{L}$ ); rAsp f 3: $597 \pm 807 \mathrm{EU} / \mathrm{L}$ (range: $48-2303 \mathrm{EU} / \mathrm{L}$; median: $319.0 \mathrm{EU} / \mathrm{L}$ ); rAsp f 4: $46 \pm 41 \mathrm{EU} / \mathrm{L}$ (range: $2-118 \mathrm{EU} / \mathrm{L}$; median: $44.0 \mathrm{EU} / \mathrm{L}$ ); rAsp f 6: $54.9 \pm 57 \mathrm{EU} / \mathrm{L}$ (range: 1-165 EU/L; median: $48.0 \mathrm{EU} / \mathrm{L}$ ). Reference values (12) were $\mathrm{rAsp} \mathrm{f}$ 1: $<9.6 \mathrm{EU} / \mathrm{L} ;$ rAsp f 3: $<13.2 \mathrm{EU} / \mathrm{L} ;$ rAsp f 4: $<8.4 \mathrm{EU} / \mathrm{L}$; rAsp f 6: $<7.2 \mathrm{EU} / \mathrm{L}$, respectively. Specific IgG against $A$. fumigatus was $215 \pm 123 \mathrm{kU} / \mathrm{mL}$ (range: $94-394 \mathrm{kU} / \mathrm{L}$; median: $170.0 \mathrm{kU} / \mathrm{L}$ ); reference value was $<20 \mathrm{kU} / \mathrm{mL}$. Thirteen of 17 patients were chronically colonized with $P$. aeruginosa (two positive sputum samples within $6 \mathrm{mo}$ ). The patients were on their regular therapeutic regimen, which includes inhalation of $\beta$-2-mimetics, chest physiotherapy, high caloric intake, and enzyme and vitamin substitution, but none of them received systemic corticosteroids 1 mo before blood samples were taken. In all patients, A. fumigatus was isolated at least once in sputum. A group of 17 healthy children and adults (mean age: $30.6 \pm 14.9$ y) served as controls (Table 1). The study was approved by the local ethical committee of the University of Bern, Switzerland, and written informed consent was obtained from all patients and/or their parents.

Antigens. IgE binding properties and characterization of recombinant $A$. fumigatus antigens were previously described (6-8); rAsp f 3 , a protein homologous to peroxisomal proteins of Candida boidinii, rAsp f 4, an allergen with unknown biologic function, and A. fumigatus manganese-dependent superoxide dismutase ( $\mathrm{rAsp} \mathrm{f} 6$ ) were cloned from an A. fumigatus cDNA library and displayed on pJuFo-phage surface. The regions coding for the mature proteins were subcloned into the $\mathrm{p}[\mathrm{His}]_{6}$-DHFR high level expression vector. Constructs were verified by nucleotide sequence determinations and used to produce hexahistidine-tagged recombinant proteins in Escherichia coli. Purity and molecular size of the proteins were analyzed by polyacrylamide gradient gels and by Western blot analysis using standard procedure (8). A. fumigatus antigens were used alone or in combination at titrated doses between 0.1 and $1 \mu \mathrm{M}$ concentrations. A P. aeruginosa strain, isolated from one CF patient (University Children's Hospital, Bern, Switzerland) was heat inactivated by $56^{\circ} \mathrm{C}$ for $30 \mathrm{~min}$. Titrated doses of $0.26-26.6 \mu \mathrm{g} / \mathrm{mL}$ protein content were used. Tetanus toxoid(Serum Institute, Bern, Switzerland) was used at $10 \mu \mathrm{g} / \mathrm{mL}$ as control.

T-cell cultures. Peripheral blood mononuclear cells (PBMC) were isolated by Ficoll (Biochrom, Berlin, Germany) density gradient centrifugation. Cells were washed three times and resuspended in RPMI 1640 medium supplemented as described (22). Cytokine secretion of polyclonally stimulated cells was determined in supernatants of $5 \times 10^{5}$ cells, in $500 \mu \mathrm{L}$ of medium, in 48-well plates. The cells were stimulated with an $\mathrm{MAb}$ mixture containing $0.5 \mu \mathrm{g} / \mathrm{mL}$ of each of the anti-CD2 (4B2 and 6G4), anti-CD28 (15E8; CLB, Amsterdam, The Netherlands), and anti-CD3 (CRL 8001; American Type Culture Collection, Manassas, VA) MAb. Supernatants of triplicate cultures were taken after $72 \mathrm{~h}$. Five $\times 10^{5}$ cells $/ 500 \mu \mathrm{L}$ were stimulated in a 48-well plate with recombinant $A$. fumigatus antigens, rAsp f 3, rAsp f 4, rAsp f 6, and $P$. aeruginosa. Supernatants were harvested on day 5 for cytokine detection. Proliferation was measured in parallel cultures $20 \mathrm{~h}$ after the addition of $1 \mu \mathrm{Ci}$ of $\left[{ }^{3} \mathrm{H}\right]$ thymidine/well in 96-well plates (DuPont/New England Nuclear, Boston, MA). Incorporation of the labeled nucleotide was determined in an LKB beta plate 
Table 1. Clinical and serological characteristics

\begin{tabular}{|c|c|c|c|c|}
\hline & All patients & non-ABPA & ABPA & $\begin{array}{l}\text { Control group } \\
\text { (reference values) }\end{array}$ \\
\hline Male/female & $9 / 8$ & $5 / 5$ & $5 / 2$ & $7 / 10$ \\
\hline Age $(y)$ & $\begin{array}{c}20.0 \pm 10.2 \\
(8-44.5)\end{array}$ & $\begin{array}{c}21.4 \pm 10.1 \\
(12.6-44.5)\end{array}$ & $\begin{array}{c}17.9 \pm 10.9 \\
(8.0-39)\end{array}$ & $\begin{array}{c}30.6 \pm 14.9 \\
(10-50)\end{array}$ \\
\hline FEV1 (\% predicted) & $\begin{array}{c}60.1 \pm 24.3 \\
(30-100)\end{array}$ & $\begin{array}{l}52.7 \pm 23.5 \\
\quad(30-95)\end{array}$ & $\begin{array}{c}71.0 \pm 23.1 \\
(30-100)\end{array}$ & $>80$ \\
\hline FVC (\% predicted $)$ & $\begin{array}{c}74.1 \pm 22.0 \\
(36-105)\end{array}$ & $\begin{array}{c}65.0 \pm 20.8 \\
(36-99)\end{array}$ & $\begin{array}{c}87.1 \pm 17.4 \\
(57-105)\end{array}$ & $>80$ \\
\hline A. fumigatus in sputum & 10 & 3 & 7 & 0 \\
\hline Total IgE & $\begin{array}{c}926.1 \pm 1508.8 \\
(8-5662)\end{array}$ & $\begin{array}{c}68.9 \pm 47.3 \\
\quad(8-145)\end{array}$ & $\begin{array}{c}2150.7 \pm 1758.8 \\
(500-5662)\end{array}$ & $<70$ \\
\hline A. fumigatus-specific IgE RAST class & $\begin{array}{l}1.9 \pm 2.1 \\
\quad(0-5)\end{array}$ & $\begin{array}{l}0.2 \pm 0.4 \\
(0-1)\end{array}$ & $\begin{array}{c}4.3 \pm 0.8 \\
(3-5)\end{array}$ & $(0-2)$ \\
\hline A. fumigatus-specific IgG (ELISA, kU/L) & $\begin{array}{c}133.0 \pm 109.4 \\
\quad(18-384)\end{array}$ & $\begin{array}{c}95.1 \pm 106.6 \\
(18-341)\end{array}$ & $\begin{array}{c}215.4 \pm 123.5 \\
(94-384)\end{array}$ & $(<20)$ \\
\hline rAsp f 4-specific $\operatorname{IgE}(\mathrm{U} / \mathrm{mL})$ & $\begin{array}{c}20.4 \pm 33.5 \\
\quad(0-118)\end{array}$ & $\begin{array}{c}2.3 \pm 1.9 \\
(0-5)\end{array}$ & $\begin{array}{c}46.3 \pm 40.7 \\
(2-118)\end{array}$ & $(<8.4)$ \\
\hline rAsp f 6-specific $\operatorname{IgE}(\mathrm{U} / \mathrm{mL})$ & $\begin{array}{c}26.0 \pm 43.6 \\
(0-165)\end{array}$ & $\begin{array}{l}5.8 \pm 11.5 \\
(0-38)\end{array}$ & $\begin{array}{c}54.8 \pm 56.7 \\
(1-165)\end{array}$ & $(<7.2)$ \\
\hline
\end{tabular}

reader (Wallac-Pharmacia, Turku, Finland). IL-10 was neutralized in cultures with $5 \mu \mathrm{g} / \mathrm{mL}$ rat anti-IL-10R (3F9-2) and anti-IL-10 MAb (JES3-19F1) (23). Rat IgG (Sigma Chemical Co., St. Louis, MO) or mouse IgG1 (Coulter Corp., Miami, FL) served as controls. The synthesis of IL-10R-associated kinases Jak 1 and Tyk 2 was blocked by preincubation of PBMC with antisense oligonucleotides Jak 1 (AS): GGTTGCATCTGGAATCTTT and Tyk 2 (AS): CCAACTTTATGTGCAATGTG; Jak 1 scrambled: TTGTGAACTGCCTGTGATT and Tyk 2 sense: CACATTGCACATAAAGTTGG, were used as control (26). All oligonucleotides were optimized in titrated doses and finally used at $1-\mu \mathrm{M}$ doses.

Quantification of cytokines. The solid-phase ELISA for IFN- $\gamma$, IL-10, and IL-13 was performed as described previously $(27,28)$. Intracytoplasmic IFN- $\gamma$, IL-10, and IL-13 were detected in PBMC stimulated with $50 \mathrm{ng} / \mathrm{mL}$ phorbol ester and $500 \mathrm{ng} / \mathrm{mL} \mathrm{Ca}^{++}$Ionophore (both from Sigma Chemical Co.) for $5 \mathrm{~h}, 2 \mu \mathrm{M}$ of monensin was added to cultures during the last $4 \mathrm{~h}$. Cells were incubated with PE-labeled anti-IL-10, anti-IL13, and FITC-labeled anti-INF- $\gamma$ antibodies (all from PharMingen)) for $40 \mathrm{~min}$ at room temperature. FITC- or PE-labeled rat IgG1 and mouse IgG1 were used as isotype control antibodies. The multicolor analysis was performed on an Epics Profile Flow cytometer (Coulter Corp.) with Argon laser (488 $\mathrm{nm})$.

Statistical analysis. Nonparametric statistical comparison of cytokine production and proliferation of cells from each individual was performed by Wilcoxon signed-rank test. Nonparametric statistical comparison between different groups was performed by Mann Whitney $U$ test.

\section{RESULTS}

PBMC of CF patients produce high IL-10 in comparison with healthy controls. A dysregulated cytokine response seems to be an important regulating event in the inflammatory response in CF. For analysis of their role in CF, IL-10, IFN- $\gamma$, and IL-13 were measured in 5-d supernatants of PBMC stimulated with anti-CD2, anti-CD3, and anti-CD28 MAb combination (Fig. $1 A$ ). CF patients showed significantly higher IL-10 production compared with the controls $(p<0.05)$. There was no difference in IL-13 and IFN- $\gamma$ production. For supporting these findings, PBMC were stimulated with phorbol ester and $\mathrm{Ca}^{++}$ionophore and intracytoplasmic IL-10 was stained in fixed and permeabilized cells. CF patients' T-cells expressed higher IL-10 in comparison with controls. The increase in intracytoplasmic IL-10 content between unstimulated and stimulated cells was significantly higher in CF patients compared with controls $(p=0.003$; Fig. $1 B)$. There was no difference in intracytoplasmic IL-13 and IFN- $\gamma$ expression between patients and controls (data not shown).

IL-10 regulates specific $T$-cell proliferation to $A$. fumigatus and $\boldsymbol{P}$. aeruginosa. For determining antigenic properties of recombinant $A$. fumigatus antigens and heat-inactivated $P$. aeruginosa, PBMC of CF patients and controls were stimulated with $P$. aeruginosa and rAsp f 3, rAsp f 4, and rAsp f 6 . Figure 2 shows mean and SE of stimulation indexes of patients and controls. Significantly increased T-cell proliferation with these antigens (stimulation index $>2$ ) was observed in $69 \%$ of patients and $17 \%$ of healthy controls. Tetanus toxoid stimulated $\mathrm{T}$-cell proliferation in all patients and controls as a control antigen.

For analysis of the role of endogenous IL-10 in the control of specific immune response against $A$. fumigatus and $P$. aeruginosa, the IL-10R was blocked and the released IL-10 was neutralized. Figure 3 depicts the proliferation under stimulation with a mixture of rAsp f 3 , rAsp f 4 , rAsp f 6 , and $P$. aeruginosa as well as under blocking the influence of endogenous IL-10 with MAb specific to IL-10 and IL-10R. Com- 
A

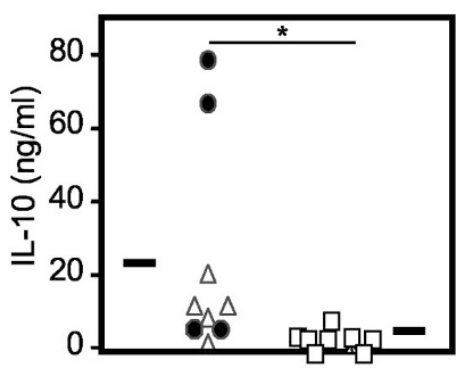

B
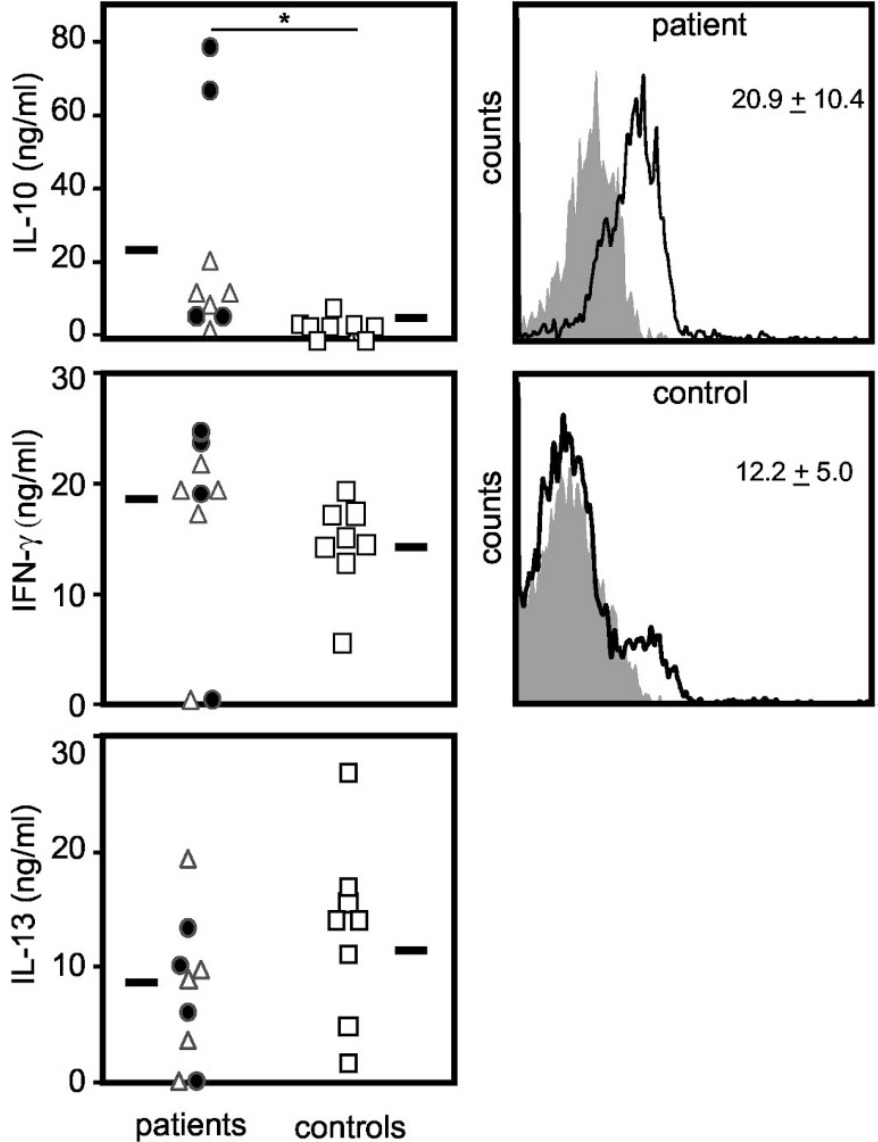

Figure 1. Increased IL-10 production in PBMC of CF patients. (A) IL-10, IFN- $\gamma$, and IL-13 production of CF patients $(n=9)$ and controls $(n=8)$ were measured in 5-d supernatants after stimulation by anti-CD2, anti-CD3, antiCD28 MAb. Triangles indicate ABPA patients. CF patients produced significantly more IL-10 compared with controls. No difference was detected between ABPA and non-ABPA patients. ${ }^{*} p<0.05$. (B) PBMC of patients and controls were stimulated for $5 \mathrm{~h}$ with phorbol ester and $\mathrm{Ca}^{++}$ionophore and for $4 \mathrm{~h}$ with monensin. Intracytoplasmic IL-10 was stained in fixed and permeabilized cells. CF patient's T-cells expressed higher IL-10 increase in comparison to controls. FACS analysis of cells from one patient and one control is shown representative of six patients and six controls. Mean intracellular IL-10 of patients and controls is given with SD in the upper right quadrant.

pared with unstimulated cells, PBMC showed significantly increased proliferation when stimulated with $\mathrm{rAsp} \mathrm{f} 3, \mathrm{rAsp} \mathrm{f} 4$, and rAsp f $6(p=0.002)$, which showed a further increase when the effect of endogenous IL-10 was blocked $(p=0.035)$. A significant T-cell proliferation was observed by $P$. aeruginosa stimulation $(p=0.02)$, as well as under IL-10 blocking conditions $(p=0.043)$. There was no significant difference in specific $A$. fumigatus- or $P$. aeruginosa-induced T-cell proliferation between CF patients with and without ABPA. Healthy individuals did not show significant proliferation by $A$. fumigatus and $P$. aeruginosa stimulation as well as under IL-10 blocking conditions. These data suggest that aspergillus- and pseudomonas-specific proliferation of T-cells in CF is under the suppressive control of endogenous IL-10.

Endogenous IL-10 suppresses IFN- $\gamma$ response to $A$. fumigatus and $P$. aeruginosa in $C F$. Cytokine production of

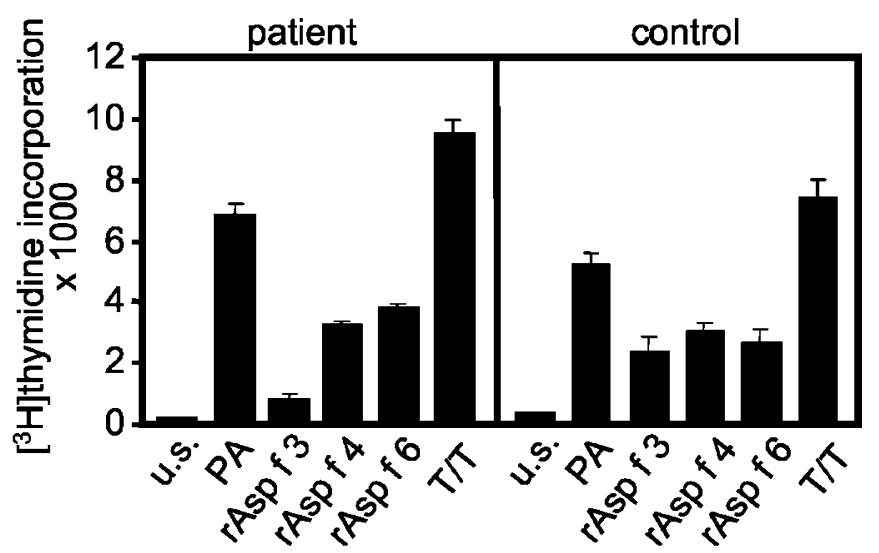

Figure 2. T-cell proliferation by $P$. aeruginosa and recombinant $A$. fumigatus antigens. PBMC of $\mathrm{CF}$ patients and controls were stimulated with titrated doses of heat-inactivated $P$. aeruginosa (PA) and recombinant A. fumigatus antigens rAsp f 3 , rAsp f 4 , and rAsp f $6 .\left[{ }^{3} \mathrm{H}\right]$ thymidine incorporation was measured after $5 \mathrm{~d}$ in triplicate. Data are shown as mean and SE of patients and controls at optimal doses of rAsp f 3 , rAsp f 4 , rAsp f $6(1 \mu \mathrm{M})$, P. aeruginosa $(26 \mu \mathrm{g} / \mathrm{mL})$, and tetanus toxoid $(10 \mu \mathrm{g} / \mathrm{mL})$ from PBMC; u.s., unstimulated.

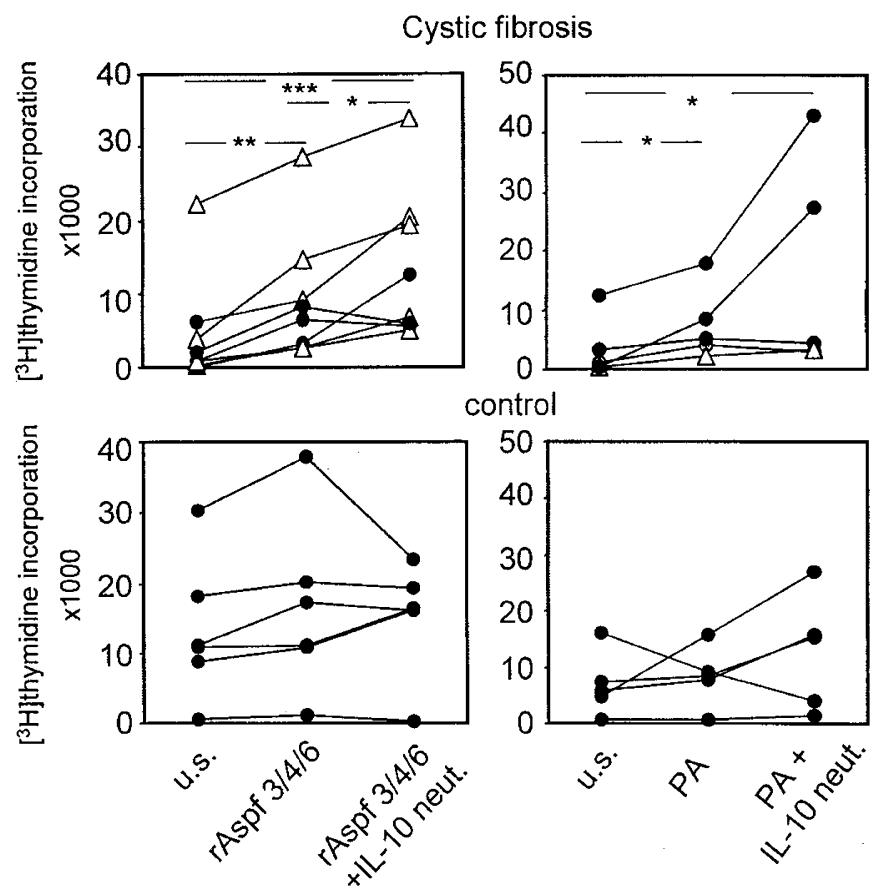

Figure 3. Regulation of T-cell response to A. fumigatus and P. aeruginosa by IL-10. IL-10R was blocked by anti-IL-10R MAb, and released IL-10 was neutralized by anti-IL-10 MAb (IL-10 neut.) in rAsp f 3, rAsp f 4, rAsp f 6 mixture (each $0.1 \mu \mathrm{M}$; eight patients, six controls) and P. aeruginosa $(2.6 \mu \mathrm{g}$ protein $/ \mathrm{mL}$ ) stimulated PBMC (five patients, six controls). $\triangle$, ABPA patients; -, non-ABPA patients. Results of $\left[{ }^{3} \mathrm{H}\right]$ thymidine incorporation after $5 \mathrm{~d}$ of stimulation are given as mean \pm error bars of triplicates. ${ }^{*} p<0.05$, ** $p<$ $0.01, * * * p<0.001$.

specifically stimulated cells was studied in PBMC of CF patients that were stimulated with rAsp f 3 , rAsp f 4, rAsp f 6, and $P$. aeruginosa. A significant increase in IL-10 production by $A$. fumigatus and $P$. aeruginosa antigens $(p<0.05)$ but no significant change in IFN- $\gamma$ was observed (Fig. 4). Interestingly, IFN- $\gamma$ significantly increased by suppressing endogenous IL-10 in A. fumigatus - and P. aeruginosa-stimulated 

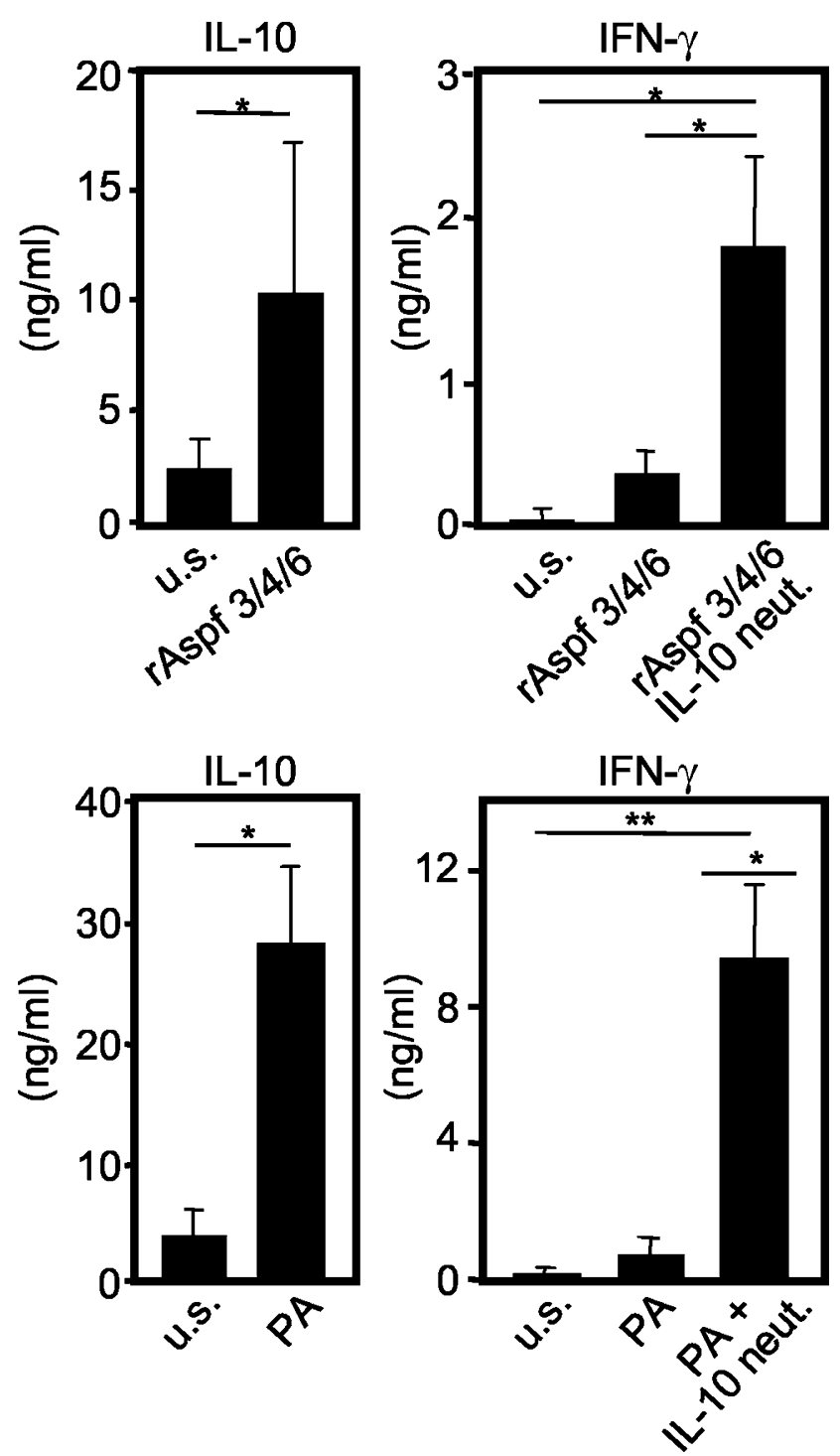

Figure 4. IL-10 controls IFN- $\gamma$ response to A. fumigatus and $P$. aeruginosa in CF patients. IL-10 and IFN- $\gamma$ production was measured in 5-d supernatants of PBMC of CF patients stimulated with rAsp f 3, rAsp f 4 , rAsp f $6(0.1 \mu \mathrm{M})$ $(n=7)$, and $P$. aeruginosa $(2.6 \mu \mathrm{g}$ protein $/ \mathrm{mL} ; n=5)$ as well as IL-10 and IL-10R blocking conditions (IL-10 neut.); ${ }^{*} p \leq 0.05,{ }^{* *} p \leq 0.01$.

cells compared with nonstimulated cells $(p<0.05$ and $p<$ 0.01 , respectively). It is known that the release of proinflammatory cytokines correlates with the intensity of inflammation, and these data demonstrate that $P$. aeruginosa- and A. fumigatus-induced IFN- $\gamma$ production is strongly controlled by IL-10. This mechanism may play a decisive immunoregulatory role in the control of the inflammatory response in CF.

Regulation of T-cell proliferation by IL-10R-associated kinases Jak 1 and Tyk 2. The regulatory role of endogenous IL-10 in the control of T-cell response was demonstrated by blocking the IL-10R-associated kinases Jak 1 and Tyk 2 using antisense oligonucleotides. Because polyclonal stimulation of PBMC showed significantly high IL-10 secretion, we determined whether background proliferation of unstimulated PBMC is controlled by IL-10R-mediated signals. PBMC of three $\mathrm{CF}$ patients were preincubated for $24 \mathrm{~h}$ with antisense oligonucleotides to Jak 1 and Tyk 2. Scrambled sense oligo- nucleotides of Jak 1 and sense oligonucleotides of Tyk 2 were used as controls. After $24 \mathrm{~h}$ of incubation with antisense oligonucleotides to IL-10R-associated kinases Jak 1 and Tyk 2 , the proliferation of resting PBMC significantly increased compared with sense and scrambled oligonucleotide controls (Fig. 5). Similarly blocking of the IL-10R also increased the background proliferation by PBMC. Accordingly, background proliferation of $\mathrm{PBMC}$, which represents in vivo-activated T-cell response, is actively suppressed by IL-10. Blocking of the receptor as well as inhibition of IL-10R-associated kinases leads to increase in T-cell proliferation.

\section{DISCUSSION}

The present study demonstrates that IL-10 plays an essential role in the control of A. fumigatus- and P. aeruginosa-induced T-cell responses in CF patients. IL-10 is a potent antiinflammatory cytokine, which acts by inhibiting the synthesis of proinflammatory cytokines of monocytes/macrophages (18, 29), T-cells (30), neutrophils (31), eosinophils (32), mast cells (33), and dendritic cells $(34,35)$ as well as human alveolar macrophages (36). In addition, IL-10 down-regulates the antigen-presenting capacity of monocytes by down-regulating MHC class II molecules and costimulatory ligands for T-cells (18). The present data demonstrate that PBMC of CF patients secrete more IL-10 than healthy individuals after polyclonal T-cell stimulation. Thus, IL-10-mediated suppressor pathways may be relevant in the regulation of the inflammatory response to microbial agents in CF.

Usually, A. fumigatus is found within the mucus, impacted in the airways without evidence of tissue invasion, and it is frequently isolated from CF respiratory secretions $(2,37)$. Although there is evidence for an immunologic response in many patients with A. fumigatus-positive cultures, they may

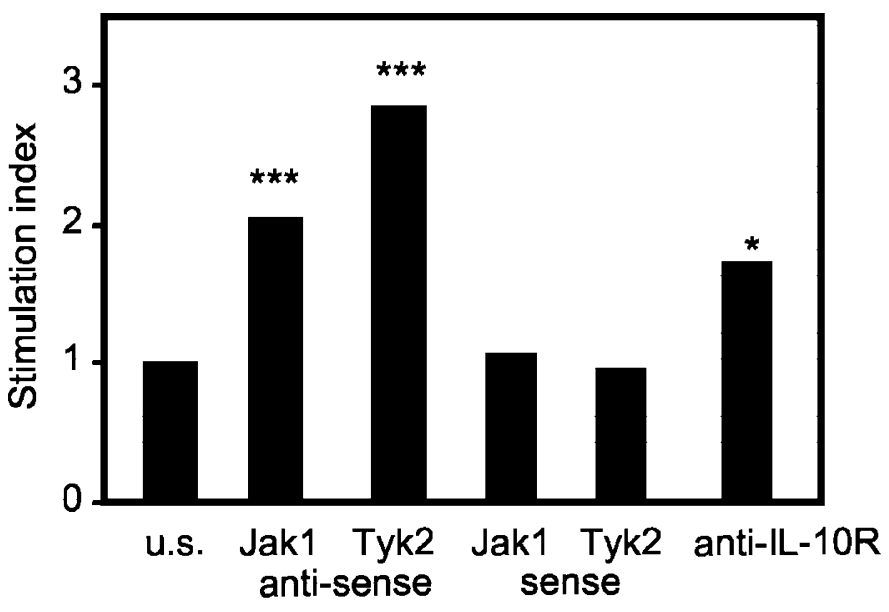

Figure 5. Regulation of T-cell proliferation by IL-10R-associated kinases Jak 1 and Tyk 2. The synthesis of IL-10R-associated kinases Jak 1 and Tyk 2 was blocked in PBMC of three CF patients, which were preincubated for $24 \mathrm{~h}$ with antisense (AS) oligonucleotides Jak 1 AS and Tyk 2 AS. As controls, Jak 1 scrambled sense and Tyk 2 sense were used. Stimulation index of $\left[{ }^{3} \mathrm{H}\right]$ thymidine incorporation of one patient is shown. The experiment was repeated three times with similar results. The proliferation of resting unstimulated T-cells significantly increased after blocking the IL-10R-associated kinases and IL$10 \mathrm{R} ; * p<0.05, * * * p<0.001$. 
not necessarily have ABPA, because immunologic response may vary over time. Why the immune system is not able to eliminate definitively the fungus from the bronchial tree is still not clear. The presence of a tolerance mechanism would, at least in part, explain this clinical observation. In the present study, specific T-cell suppressive effects of endogenous IL-10 could clearly be shown by a significant increase of cell proliferation after the endogenous IL-10 influence was inhibited. A significant increase in IFN- $\gamma$ production after blocking endogenous IL-10 was detected after stimulation with recombinant A. fumigatus antigens. Previously, a Th2-like cytokine pattern described in A. fumigatus stimulated PBMC from patients with ABPA (38). A. fumigatus-specific cell lines secreted predominantly IL- 4 after $48 \mathrm{~h}$ of culture, and IFN- $\gamma$ and IL-2 were not detectable (39). Apparently, endogenous IL-10 is able to control IFN- $\gamma$ levels in CF efficiently. This explains the low quantities of IFN- $\gamma$ production, previously observed in $\mathrm{CF}$ patients by different stimulatory conditions (40). The role of IL-10 in the immune response of mice to A. fumigatus was studied in a murine ABPA model (41). IL-10-deficient mice showed a high mortality, and their lung cells produced exaggerated amounts of IL-4, IL-5, and IFN- $\gamma$ compared with wild-type mice, demonstrating IL-10 as a natural suppressor of cytokine production and inflammation.

Binding of IL-10 to the extracellular domain of the IL-10R activates the phosphorylation of the receptor-associated Jak 1 and Tyk 2 for transcription (42). Therefore, the influence of IL-10 on T-cell proliferation was additionally studied by incubating the cells with antisense oligonucleotides, which block the transcription of Jak 1 and Tyk 2 and thus the IL-10 action. By preincubation with antisense oligonucleotides, PBMC of CF patients showed increased proliferation. This provides additional evidence for the control of T-cell responses by IL-10 in microbial infection. Unfortunately, the antisense approach does not allow generation of antigen-specific cultures because of decreased antigen-presenting cell capacity of monocytes and B-cells in PBMC because of plastic adhesion and decreased viability of these cells, as a result of incubation with oligonucleotides.

CF patients have a bronchial tree chronically colonized with $P$. aeruginosa from early childhood on, despite intact defense mechanisms against microorganisms outside the lung. Current management of pulmonary disease in $\mathrm{CF}$ is directed as a consequence of infection and inflammation (1). Despite an intense host inflammatory reaction with progressive suppurative pulmonary disease resulting from $P$. aeruginosa colonization (43), the bacteria are not eliminated. Thus, one may argue that tolerance mechanisms against this microorganism may develop. Indeed, PBMC of CF patients produced high amounts of IL-10 by $P$. aeruginosa stimulation. Blocking of endogenous IL-10 leads to high IFN- $\gamma$ production and T-cell proliferation, indicating that IL-10 is actively down-regulating the ongoing inflammatory response against $P$. aeruginosa. The control of $P$. aeruginosa-induced inflammation by IL-10 was furthermore demonstrated in IL-10-deficient mice, which showed an increased area of lung inflammation and more severe weight loss after inoculation of $P$. aeruginosacontaining agar beads into their lung. In contrast, IL-10- treated mice showed less severe weight loss, fewer BAL neutrophils, and smaller areas of lung inflammation (44).

The present study dissects A. fumigatus-specific immune response by using recombinant antigens. Previous studies were performed with aspergillus extracts, which may contain a nonstandard mixture of antigens, nonantigenic proteins, and cell toxic proteins (45). However, a crude P. aeruginosa antigen was used because recombinant protein antigens are currently not available. This extract contains lipopolysaccharide and other Gram-negative cell-wall products and DNA. In addition to cell wall products, bacterial DNA may display stimulatory effects on mammalian immune cells, and $\mathrm{CpG}$ oligonucleotide-containing DNA of $P$. aeruginosa may contribute to the stimulatory effects on PBMC of CF patients and controls (46). Together, these data demonstrate that IL-10 plays an essential role in tolerance against $A$. fumigatus and $P$. aeruginosa in the lungs of $\mathrm{CF}$ patients. Moreover, severe destructive effects of the immune response against antigens of A. fumigatus and lipopolysaccharide, lipopolysaccharide-like cell-wall products, and $\mathrm{CpG}$ oligonucleotide-containing DNA of $P$. aeruginosa are efficiently controlled by endogenous IL-10. Moreover, this mechanism may provide an explanation for the existential survival strategy of certain microorganisms in the lungs of CF patients.

Acknowledgments. The authors thank Dr. Kevin Moore (DNAX Research Institute, Palo Alto, CA) for the anti-IL$10 \mathrm{R} \alpha$ and anti-IL-10 MAb and Christopher H. Heusser (Novartis, Basel, Switzerland) for antibodies to IL-4 and IFN- $\gamma$.

\section{REFERENCES}

1. Ramsey BW 1996 Drug therapy: management of pulmonary disease in patients with cystic fibrosis. N Engl J Med 335:179-188

2. Nelson LA, Callerame ML, Schwartz RH 1979 Aspergillosis and atopy in cystic fibrosis. Am J Respir Dis 120:863-873

3. Nikolaizik WH, Brueton MJ, Warner JO 1991 Aspergillus allergy and allergic bronchopulmonary aspergillosis in cystic fibrosis. Pediatr Allergy Immunol 2:83-86

4. Scheiner O 1992 Recombinant allergens: biological, immunological and practical aspects. Int Arch Allergy Immunol 98:93-96

5. Moser M, Crameri R, Menz G, Schneider T, Dudler T, Virchow C, Gmach M, Blaser K, Suter M 1992 Cloning and expression of recombinant Aspergillus fumigatus allergen I/a (rAsp.f./a) with IgE binding and type 1 skin test reactivity. J Immunol 49:454-460

6. Crameri R, Blaser K 1996 Cloning Aspergillus fumigatus allergens by the pJuFo filamentous phage display system. Int Arch Allergy Immunol 110:41-45

7. Crameri R, Hemmann St, Ismail C, Menz G, Blaser K 1998 Disease-specific recombinant allergens for the diagnosis of allergic bronchopulmonary aspergillosis. Int Immunol 10:1211-1216

8. Crameri R 1998 Recombinant Aspergillus fumigatus allergens: from the nucleotide sequences to clinical application. Int Arch Allergy Immunol 115:99-114

9. Nikolaizik WH, Moser M, Crameri R, Little S, Warner JO, Blaser K, Schöni MH 1995 Identification of allergic bronchopulmonary Aspergillosis in cystic fibrosis patients by recombinant Aspergillus fumigatus I/a-specific serology. Am J Respir Crit Care Med 152:634-639

10. Hemmann St, Nikolaizik WH, Schöni MH, Blaser K, Crameri R 1998 Differential IgE recognition of recombinant Aspergillus fumigatus allergens by cystic fibrosis patients with allergic bronchopulmonary aspergillosis and Aspergillus allergy. Eur J Immunol 28:1155-1160

11. Suter S, Schaad UB, Roux-Lombard P, Girardin E, Grau G, Dayer JM 1989 Relation between TNF and granulocyte elastase-alpha1-proteinase inhibitor complexes in the plasma of patients with cystic fibrosis. Am Rev Respir Dis 140:1640-1644

12. Willmott RW, Vociela V, Frenke M 1991 Relationship of peripheral blood cytokine concentration and cytokine production to clinical status in cystic fibrosis. Pediatr Pulmonol Suppl 6:303A

13. Bonfield TL, Panuska IR, Konstan MW, Hilliard KA, Ghnaim JB, Berger M 1995 Inflammatory cytokines in cystic fibrosis lungs. Am J Respir Crit Care Med 152:2111-2118

14. Konstan MW, Hilliard KA, Norwell TM, Berger M 1994 Bronchoalveolar lavage findings in cystic fibrosis patients with stable, clinically mild lung disease suggest ongoing infection and inflammation. Am J Respir Crit Care Med 150:448-454 
15. Kahn TZ, Wagener JS, Bost T 1995 Early pulmonary inflammation in infants with cystic fibrosis. Am J Respir Crit Care Med 151:1075-1082

16. Weiss SJ 1989 Tissue destruction by neutrophils. N Engl J Med 320:365-376

17. Fiorentino DF, Zlotnik A, Mosmann TR, Howard M, O'Garra A 1991 IL-10 inhibits cytokine production by activated macrophages. J Immunol 147:3815-3822

18. De Waal Malefyt R, Abrams J, Bennett B, Figdor CG, De Vries JE 1991 Interleukin 10 (IL-10) inhibits cytokine synthesis by human monocytes: an autoregulatory role of IL-10 produced by monocytes. J Exp Med 174:1209-1220

19. Hsu D-H, Moore KW, Spits H 1992 Differential effects of interleukin-4 and -10 on interleukin-2 induced interferon- $\gamma$ synthesis and lymphokine activated killer activity. Int Immunol 4:563-569

20. Del Prete G, DeCarli M, Almerigogna F, Giudizi MG, Biagiotti R, Romagnani S 1993 Human IL-10 is produced by both type 1 helper (Th1) and type 2 (Th2) cell clones and inhibits their antigen-specific proliferation and cytokine production. J Immunol 150:353-360

21. Bacetta R, Bigler M, Touraine J-L, Parkman R, Tovo P-A, Abrams J, de Waal Malefyt R, De Vries JE, Roncarolo MG 1994 High levels of interleukin 10 production in vivo are associated with tolerance in SCID patients transplanted with HLAmismatched hematopoietic stem cells. J Exp Med 179:493-502

22. Akdis CA, Blesken T, Akdis M, Wüthrich B, Blaser K 1998 Role of interleukin 10 in specific immunotherapy. J Clin Invest 102:98-106

23. Akdis CA, Joss A, Akdis M, Faith A, Blaser K 2000 A molecular basis for T cell suppression by IL-10: CD28-associated IL-10 receptor inhibits CD28 tyrosine phosphorylation and phosphatidylinositol 3-kinase binding. FASEB J 14:1666-1668

24. Finbloom DS, Winestock KD 1995 IL-10 induces the tyrosine phosphorylation of Tyk2 and Jak1 and the differential assembly of STAT $\alpha$ and STAT3 complexes in human T cells and monocytes. J Immunol 155:1079-1090

25. Kotenko SV, Krause CD, Izotova LS, Pollak BP, Wo W, Pestka S 1997 Identification and functional characterization of a second chain of the interleukin-10 receptor complex. EMBO J 16:5894-5903

26. Roy B, Cathcart MK 1998 Induction of 15-lipooxygenase expression by IL-13 requires tyrosine phosphorylation of Jak 2 and Tyk 2 in human monocytes. J Biol Chem 273:32023-32029

27. Akdis CA, Blesken T, Akdis M, Alkan SS, Wuthrich B, Heusser CH, Blaser K 1997 Induction and differential regulation of bee venom phospholipase A2-specific human $\mathrm{IgE}$ and IgG4 antibodies in vitro requires allergen-specific and nonspecific activation of T and B cells. J Allergy Clin Immunol 99:345-353

28. Akdis CA, Akdis M, Blesken T, Wymann D, Alkan SS, Müller U, Blaser K 1996 Epitope-specific $\mathrm{T}$ cell tolerance to phospholipase A2 in bee venom immunotherapy and recovery by IL-2 and IL-15 in vitro. J Clin Invest 98:1676-1683

29. Moore KW, O`Garra A, de Waal Malefyt R, Vieira P, Mosmann TR 1993 Interleukin10. Annu Rev Immunol 11:165-190

30. Joss A, Akdis M, Faith A, Blaser K, Akdis CA 2000 IL-10 directly acts on T cells by specifically altering the CD28 co-stimulation pathway Eur J Immunol 30:1683-1690
31. Cassatella MA, Meda L, Bonora S, Ceska M, Constantin G 1993 Interleukin-10 (IL-10) inhibits the release of proinflammatory cytokines from human polymorphonuclear leukocytes: evidence for an autocrine role of tumor necrosis factor and IL-1-beta in mediating the production of IL-8 triggered by lipopolysaccharide. J Exp Med 178:2207-2211

32. Takanaski S, Nonaka R, Xing Z, Obyrne P, Dolovich J, Jordana M 1994 Interleukin 10 inhibits lipopolysaccharide-induced survival and cytokine production by human peripheral blood eosinophils. J Exp Med 180:711-715

33. Arock M, Zuanyamorim C, Singer M, Benhamou M, Pretolani M 1996 Interleukin-10 inhibits cytokine generation from mast cells. Eur J Immunol 26:166-170

34. Macatonia SE, Doherty TM, Knight SC, O'Garra A 1993 Differential effect of IL-10 on dendritic cell-induced $\mathrm{T}$-cell proliferation and interferon-gamma production. J Immunol 150:3755-3764

35. Steinbrink K, Wölfl M, Jonuleit H, Knop J, Enk AH 1997 Induction of tolerance by IL-10-treated dendritic cells. J Immunol 159:4772-4780

36. Thomassen MJ, Divis LT, Fisher CJ 1996 Regulation of human alveolar macrophage inflammatory cytokine production by interleukin-10. Clin Immunol Immunopathol 80:321-324

37. Mroueh S, Spock A 1994 Allergic bronchopulmonary aspergillosis in patients with cystic fibrosis. Chest 105:32-36

38. Skov M, Poulsen LK, Koch C 1999 Increased antigen-specific Th-2 response in allergic bronchopulmonary aspergillosis (ABPA) in patients with cystic fibrosis. Pediatr Pulmonol 27:74-79

39. Knutsen AP, Müller KR, Levine AD, Chouhan B, Hutcheson PS, Slavin RG 1994 Asp f I CD4 $+\mathrm{TH}_{2}$-like $\mathrm{T}$ cell lines in allergic bronchopulmonary aspergillosis. J Allergy Clin Immunol 94:215-221

40. Moss RB, Hsu Y-P, Olds L 2000 Cytokine dysregulation in activated cystic fibrosis (CF) peripheral lymphocytes. Clin Exp Immunol 120:518-525

41. Grünig G, Corry DB, Leach MW, Seymour BWP, Kurup VP, Rennik DM 1997 Interleukin-10 is a natural suppressor of cytokine production and inflammation in a murine model of allergic bronchopulmonary aspergillosis. J Exp Med 185:1089-1099

42. Donelly RP, Dickensheets H, Finbloom DS 1999 The interleukin-10 signal transduction pathway and regulation of gene expression in mononuclear phagocytes. J Interferon Cytokine Res 19:563-573

43. Konstan MW, Berger M 1993 Cystic Fibrosis. Marcel Dekker Inc., New York, pp. $219-276$

44. Chmiel JF, Konstan MW, Knesebeck JE, Hilliard JB, Bonfield TL, Dawson DV, Berger M 1999 IL-10 attenuates excessive inflammation in chronic Pseudomonas infection in mice. Am J Respir Crit Care Med 160:2040-2047

45. Vailes L, Sridhara S, Cromwell O, Weber B, Breitenbach M, Chapman M 2001 Quantitation of the major fungal allergens, Alt a 1 and Asp f 1 in commercial allergenic products. J Allergy Clin Immunol 107:641-646

46. Lipford GB, Heeg K, Wagner H 1998 Bacterial DNA as immune cell activator. Trends Microbiol 6:496-500 